\title{
ULTRASTRUCTURAL CHANGES IN FEMALE HEPATOCYTES DURING OVARIAN MATURATION OF Steindachnerina insculpta (PISCES: CURIMATIDAE)
}

\author{
RIBEIRO, V. M. A., BAZZOLI, N., MARIA, T. A. and SANTOS, G. B. \\ Graduate Program in Zoology of Vertebrates, Pontifical Catholic University, Belo Horizonte, Minas Gerais, Brazil \\ Correspondence to: Nilo Bazzoli, Programa de Pós-Graduação em Zoologia de Vertebrados, Laboratório de Ictiologia, \\ PUC Minas, Av. Dom José Gaspar, 500, Coração Eucarístico, CEP 30535-610, \\ Belo Horizonte, Minas Gerais, Brazil, e-mail bazzoli@pucminas.br \\ Received May 5, 2004 - Accepted May 2, 2005 - Distributed November 1, 2006
}

(With 4 figures)

\begin{abstract}
During gonadal maturation the females of Steindachnerina insculpta, a teleost of the Furnas reservoir, Minas Gerais, Brazil, show low hepatosomatic and high gonadossomatic indexes, suggesting possible transference of hepatic substances to the ovaries. In comparison to the resting phase, in the maturation/ mature one the hepatocytes show greater development of both smooth and rough endoplasmic reticula, increased electron density in the mitochondria, and glycogen scattered throughout the cytoplasm. In both resting and maturation/mature phases, the hepatic parenchyma contains melanomacrophagic centers that consist of degenerating cellular debris and are surrounded by capsules formed by cells, resembling fibroblasts, joined by desmosomes. No physiological relation of these centers with ovarian maturation was found.
\end{abstract}

Keywords: teleost fish, ovarian maturation, hepatocytes.

\section{RESUMO}

\section{Mudanças ultra-estruturais nos hepatócitos de fêmeas de Steindachnerina insculpta (Pisces: Curimatidae) durante a maturação ovariana}

Fêmeas de Steindachnerina insculpta, um teleósteo do reservatório de Furnas, Minas Gerais, Brasil, apresentaram, durante a maturação gonadal, um baixo índice hepatossomático e um alto índice gonadossomático, sugerindo que substâncias hepáticas são provavelmente transferidas para os ovários. Comparando-se fêmeas no estádio de repouso com aquelas no estádio maturação/maduro, observaramse nos hepatócitos de fêmeas no estádio maturação/maduro maior desenvolvimento do retículo endoplasmático rugoso e liso, mitocôndrias com densidade eletrônica aumentada e glicogênio espalhado por todo citoplasma. No estádio de repouso, assim como no estádio de maturação/maduro, observaram-se, no parênquima hepático, centros melanomacrofágicos constituídos de restos celulares em degeneração delimitados por cápsula contendo células semelhantes a fibroblastos unidas por desmosomas. Não foram observadas relações fisiológicas entre os centros melanomacrofágicos e a maturação dos ovários.

Palavras-chave: peixe-teleósteo, maturação ovariana, hepatócitos.

\section{INTRODUCTION}

In non-mammalian vertebrates, the vitellogenesis stage is important because in it oocytes accumulate yolk in the form of globules. These contain vitellogenin, a phospholipo-glycoprotein secreted by the hepatocytes, which is then incorporated into the oocytes by micropinocytosis, via the blood stream (Selman \& Wallace, 1989). In recent years, data has increased substantially on vitellogenesis regulation and mechanisms, i.e. multiplicity of vitellogenin $(\mathrm{Vg})$ genes, the oocyte $\mathrm{Vg}$ receptor, $\mathrm{Vg}$ processing enzymes and their 
specific yolk products, and synthesis of various vitelline envelope (VE) precursor proteins in the liver and ovary (Patiño \& Sullivan, 2002).

Vitellogenesis is regulated by estrogens produced by thecha and stromal cells in response to gonadotrophins released by the pituitary gland (Van de Hurk \& Peute, 1979). During the later stages of vitellogenesis, large amounts of yolk material, requiring fat and protein from dietary and somatic sources, are absorbed by the oocytes (Bohemen et al., 1981). Many fish stop feeding during the gonadal maturation period that precedes spawning and leads to a loss in total body and hepatic weights (Tveranger, 1985). Therefore, gonadossomatic (GSI) and hepatossomatic (HSI) indexes are accurate parameters for determining reproductive periodicity (Maddock \& Burton, 1999). In addition, differences in the distribution and degree of proliferation of rough endoplasmic reticulum (RER), smooth endoplasmic reticulum (SER), and mitochondria in the hepocytes may be related to oogenesis during ovarian maturation (Peute et al., 1978; Bohemen et al., 1981; Gillis et al., 1990).

This work studies the morphological changes in hepatocytes during the resting and maturation/ mature phases of the reproductive cycle of Steindachnerina insculpta, a small detritivorous fish species from Furnas Reservoir, the Grande River, Minas Gerais, Brazil.

\section{MATERIAL AND METHODS}

\section{Specimens}

For biometric analyses, two hundred and seventy-two adult females (ninety-one in the resting phase and one hundred eighty-one in the maturation/mature phase) were captured in the Furnas Reservoir (20 40' S and $46^{\circ} 19^{\prime} \mathrm{W}$ ) between September 1992 and August 1994. All specimens, which were captured using gill nets, were fixed in $10 \%$ formaldehyde.

\section{Gonadossomatic and hepatossomatic indexes}

After dissection, gender identification, macroscopic determination of the reproductive cycle phase, the following data were recorded for each specimen: standard length (SL), body weight (BW), and that of the gonads (GW) and liver (LW). The biometric data obtained were used for calculating the gonadosomatic $(\mathrm{GSI}=\mathrm{GW} / \mathrm{BW} \times 100)$ and hepatosomatic $(\mathrm{HSI}=\mathrm{LW} / \mathrm{BW} \times 100)$ indexes.

\section{Light microscopy}

For histological analysis of morphological changes in the hepatocytes, liver fragments of ten adult females in the resting phase and ten females in the maturation/mature one were collected. Specimens were fixed in Bouin's fluid for $12 \mathrm{~h}$, embedded in glycol metacrylate plastic resin, sectioned (3-5 $\mu \mathrm{m})$, and stained with hematoxylineosin or toluidin blue-sodium borate. To determine the content of hepatocyte glycogen and lipids, the periodic -acid Schiff (PAS) and Sudan black techniques were used, respectively. Reproductivecycle phases were confirmed histologically.

\section{Transmission electron microscopy}

The liver fragments were placed Karnovsky fixative with $0.1 \mathrm{M}$ cacodylate buffer, $\mathrm{pH}$ 7.2-7.4, at $4{ }^{\circ} \mathrm{C}$, for approximately $12 \mathrm{~h}$; post-fixed in $1 \%$ osmium tetroxide in the same buffer for $2 \mathrm{~h}$; dehydrated; and embedded in Epon 812. Ultra-thin sections were stained with $1 \%$ uranil acetate and lead citrate, and observed in an electron microscope.

\section{Statistical analysis}

A student $t$ test was performed to detect variations in the mean values of the gonadossomatic and hepatossomatic indexes calculated for resting and maturation/mature reproductive cycle phases.

\section{RESULTS}

\section{Gonadossomatic and hepatossomatic indexes}

Mean GSI increased from the resting (3.37 \pm $2.80)$ to maturation/mature $(13.17 \pm 5.09)$ phase, while the mean HSI for females decreased from the resting $(0.54 \pm 0.32)$ to maturation/mature phase $(0.37 \pm 0.24)$. The GSI and HSI mean values were statistically different $(\mathrm{p}<0.05)$ between resting and mature phases.

\section{Histological analysis of hepatocytes}

The liver of S. insculpta shows hepatocytes arranged in rows intercalated with sinusoidal capillaries Each hepatocyte contains a large, round, centrally situated nucleus with a prominent nucleolus. The hepatic parenchyma of females in the resting and maturation/mature phases showed circular structures consisting of amorphous 
material, surrounded by a thin connective capsule - the melanomacrophagic centers.

\section{Ultrastructural analysis of hepatocytes}

Female hepatocytes in the resting and maturation/mature phases showed morphological variations in rough and smooth endoplasmic reticula, mitochondria, and glycogen (Table 1, Figs. 1-2). Degenerating cellular debris surrounded by fibroblast-like cells joined by desmosomes were seen in the melanomacrophagic centers (Figs. 3-4).

TABLE 1

Main ultrastructural differences between hepatocytes during the resting and maturation/mature phases of $S$. insculpta females captured in Furnas Reservoir.

\begin{tabular}{|c|l|l|}
\hline Organelles/inclusions & \multicolumn{1}{|c|}{ Ultrastructural Characteristics of Hepatocytes } \\
\hline RER & \multicolumn{1}{|c|}{ Resting } & \multicolumn{1}{c|}{ Maturation/ Mature } \\
\hline SER & Scarce, dispersed cisterns & Abundant, parallel cisterns \\
\hline Glycogen & Poorly developed & $\begin{array}{l}\text { Abundant anostomosed networks of short } \\
\text { tubules }\end{array}$ \\
\hline Mitochondria & $\begin{array}{l}\text { Accumulated in peripheral areas of the } \\
\text { cytoplasm }\end{array}$ & Scattered throughout the cytoplasm \\
\hline
\end{tabular}

$\mathrm{RER}=$ rough endoplasmic reticulum; and SER = smooth endoplasmic reticulum.

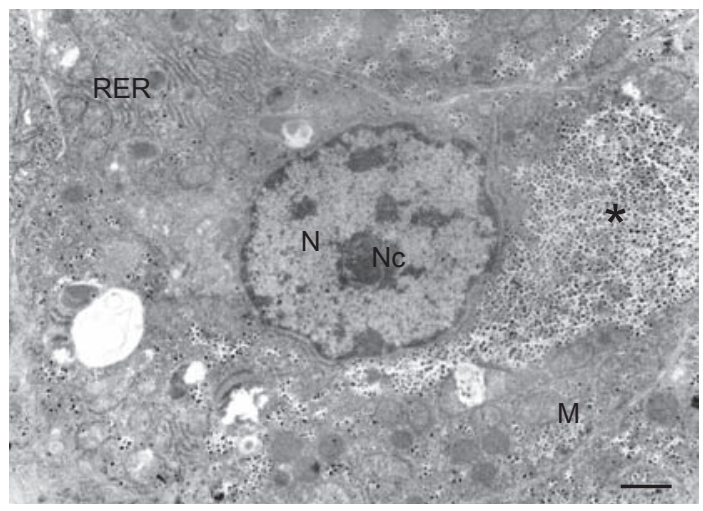

Fig. 1 - Hepatocyte of female in resting phase: rough endoplasmic reticulum (RER) with scarce, dispersed cisterns, accumulated glycogen (asterisk) in peripheral regions of the cytoplasm, and abundant mitochondria $(\mathrm{M}) . \mathrm{N}=$ nucleus; $\mathrm{Nc}=\mathrm{nu}-$ cleolus. Bar $=1.0 \mu \mathrm{m}$.

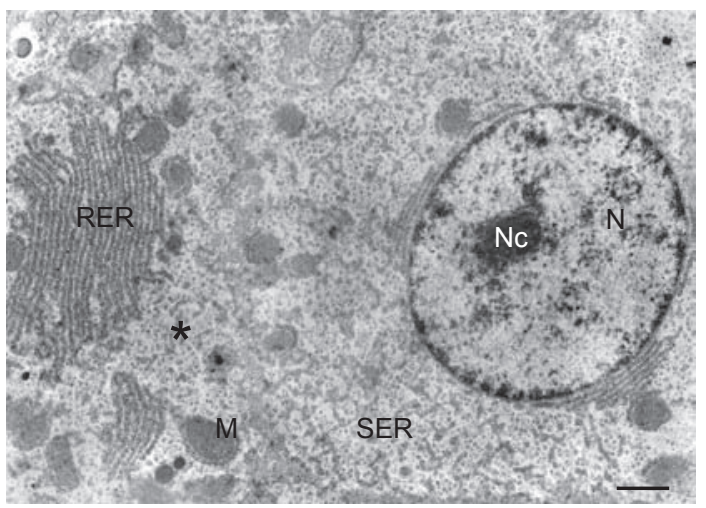

Fig. 2 - Hepatocyte of female in maturation/mature phase: rough endoplasmic reticulum (RER) with parallel cisterns, smooth endoplasmic reticulum (SER) constituted of anastomosed network of short tubules, glycogen (asterisk) dispersed throughout the cytoplasm, and mitochondria $(\mathrm{M})$ with increased electron density. $\mathrm{N}=$ nucleus; $\mathrm{Nc}=$ nucleolus. $\mathrm{Bar}=1.0 \mu \mathrm{m}$. 


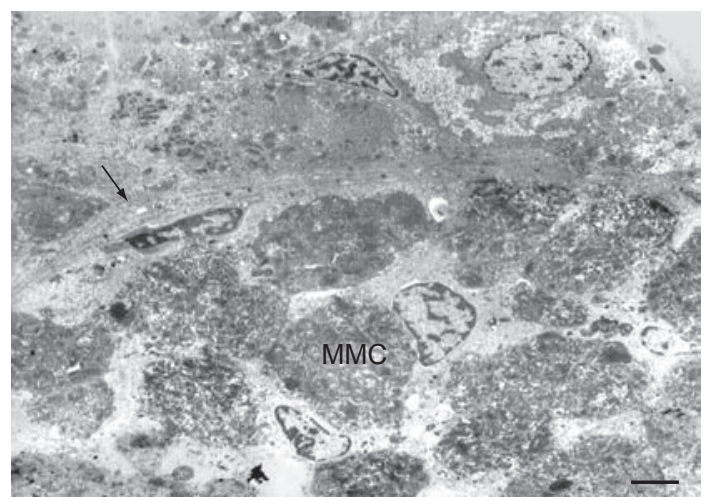

Fig. 3 - Melanomacrophagic center (MMC) containing amorphous, heterogeneous, electron dense bodies and nuclei of cells. Arrow $=$ capsule. Bar $=3.0 \mu \mathrm{m}$.

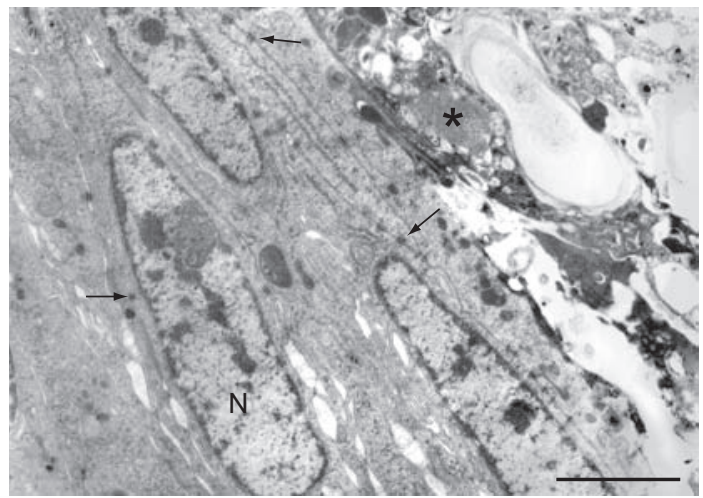

Fig. 4 - Detail of capsule of the melanomacrophagic center, with cells, resembling fibroblasts, joined by desmosomes (arrow). Nucleus $(\mathrm{N})$; amorphous material (asterisk). Bar $=1.0 \mu \mathrm{m}$.

\section{DISCUSSION}

The GSI and HSI of S. insculpta showed an inverse relation throughout the reproductive cycle, similarly to what was reported by Yoneda et al. (1998). The HSI reached higher values in the resting phase and decreased abruptly during the maturation/mature one, at which time the GSI became higher, indicating decreased hepatic reserve reserves during ovarian maturation. This is known to occur as a result of depleted storage of hepatocyte glycogen and lipids (Svedäng \& Wickström, 1997), and also because of vitellogenin synthesis and transfer to the oocytes (Luzzana et al., 1996). The HSI may also vary between species of teleosts, due to the differences in energy storage capacity, physiological condition, feeding habits, and nutrient availability (Svedäng \& Wickström, 1997). In the mature stage, female hepatocytes of S. insculpta showed RERs with proliferated cisterns arranged in parallel stacks, observed also by Bohemen et al. (1981) and Gillis et al. (1990). According to Peute et al. (1978), rapid proliferation of rough endoplasmic reticula results from increasing vitellogenin production. Bohemen et al. (1981), however, detected no vitellogenin in the liver, even in the presence of high HSI values, suggesting that this protein is released into the blood stream immediately after its synthesis by the hepatocytes. Therefore, increasing liver weight may be related to the storage of non-proteic substances and/or to the development of the organelles in these cells during vitellogenesis (Bohemen et al., 1981). The smooth endoplasmic reticula of the hepatocytes in the mature phase was proliferated, forming an extensive, anastomosed network of short tubules, which according to Leatherland \& Sonstegard (1988), is because the teleost liver is involved in metabolizing and converting sex hormones. Kime (1978) and Schulz (1986) showed 
teleost liver to be capable of converting cortisol into androgens, possibly signifying a role of the liver in normal steroidogenesis of gonadal hormones. In this study, similarly to what was reported by Peute et al. (1978), glycogen granules were grouped in peripheral cytoplasm of the hepatocytes during the resting phase, and dispersed throughout the cytoplasm during the maturation/mature phase.

Hepatocytes of $S$. insculpta females in the mature phase showed mitochondria a highly electron-sense matrix, as described by Peute et al. (1978) for Brachydanio rerio. The authors suggest that density of the mitochondria matrix during this stage results from increasing energy demand and metabolic rate related to the use of triglyceridederived free fatty acids as the oxidative substrate.

In teleosts, melanomacrophagic centers varying in number, size, and content are found in the spleen, kidneys, and liver (Herraez \& Zapata, 1991). Vogelbein et al. (1987) described these centers as a special type of granuloma formed by an accumulation of monocytes drawn from periferic circulation. Meseguer et al. (1994) observed macrophage mobility in the hepatic parenchyma and involvement of these cells in melanomacrophagic center formation. The presence of these centers in hemocytopoetic tissue is related to health, nutritional state, age, and stress, accounting for the suggested use of these structures as environmentalquality bio-indicators (Agius \& Roberts, 1981). In this study, melanomacrophagic centers located near blood vessels and containing heterogeneous pigments, similar to those observed in Carassius auratus by Herraez \& Zapata (1991), were seen in the hepatic parenchyma during both resting and maturation/mature phases. As reported by Gonzalez et al. (1993) and observed in the present work, those centers did not affect the hepatic physiology related to vitellogenin synthesis, since ovarian maturation occurred normally. In S. insculpta, the melanomacrophagic centers evolved to granulomas, a finding corroborated by the findings of Vogelbein et al. (1987) and Meseguer et al. (1994).

The first account of hepatocyte involvement in vitellogenesis, as shown by ultrastructural features of a neotropical teleost species, was carried out in the present work. However, further molecular studies must be conducted to quantify vitellogenin content throughout the reproductive cycle of Brazilian teleosts.
Acknowledgments - The authors are grateful to the staff of the Furnas Hydrobiology and Fishery Station (Furnas Centrais Elétricas S/A) for assistance during fish sampling, to the Electron Microscopy Center CEMEL/UFMG, to the Brazilian Research Foundations: CNPq, FAPEMIG, and FIP-PUC- Minas for financial support, and to Dr. Gleydes Gambogi Parreira for suggestions on the English version of the manuscript.

\section{REFERENCES}

AGIUS, C. \& ROBERTS, R. J., 1981, Effects of starvation on the melanomacrophage centers of fish. J. Fish Biol., 19: 161-169.

BOHEMEN, C. G. V., LAMBERT, J. G. D. \& PEUTE J., 1981, Annual changes in plasma liver in relation to vitellogenesis in the female rainbow trout, Salmo gairdneri. Gen. Comp. Endocrinol., 44: 94-107.

GILLIS, D. J., MCKEON B. A., \& HAY, D. E., 1990, Physiological and histological aspects of late oocyte provisioning, ovulation, and fertilization in Pacific herring (Clupea harengus pallasi). Can. J. Fish Aquat. Sci., 47: $1505-1512$.

GONZALES, G., CRESPO, S., BRUSLE, J., 1993, Histocytological study of the liver of the cabrilla sea bass, Serranus cabrilla (Teleostei, Serranidae), a avaiable model for marine fish experimental studies. J. Fish Biol., 43: 363-373

HERRAEZ, M. P. \& ZAPATA A. G., 1991, Structural characterization of the melanomacrophage centres (MMC) of goldfish Carassius auratus. Eur. J. Morphol., 29(2): 89-102.

KIME, D. E., 1978, The hepatic catabolism of cortisol in teleost fish: adrenal origin of 11-oxytestosterone precursors. Gen. Comp. Endocrinol., 35: 343-352.

LEATHERLAND, J. F. \& SONSTEGARD, R. A., 1988, Ultrastructure of the liver of Lake Erie Coho salmon from post-hatching until spawning. Cytobios, 54:195-208.

LUZZANA, U., SERRINI, G., MORETTI, V. M., GRIMALDI, P., PALEARI, M. A. \& VALFREÉ, F., 1996, Seasonal variations in fat content and fatty acid composiotion of male and female coregonid "bondella" from Lake Maggiore and landlocked shad from Lake Como (Northern Italy). J. Fish Biol., 48: 352-366.

MADDOCK, D. M. \& BURTON, M. P. M., 1999, Gross and histological observations of ovarian development and related condition changes in American plaice. J. Fish Biol., 53: 928-944.

MESEGUER J., LOPEZ-RUIZ A. \& ESTEBAN M. A., 1994, Melano-macrophages of seawater teleosts, sea bass (Dicentrarchus labrax) and gilthead seabream (Sparus aurata): morphology, formation and possible function. Cell Tissue Res., 277: 1-10.

PATIÑO, R. \& SULLIVAN, C. V., 2002, Ovarian follicle growth, maturation, and ovulation in teleost fish. Fish Physiol. Biochem., 266: 57-70.

PEUTE J., VAN DER GAAG M. A. \& LAMBERT, J. G. D., 1978, Ultrastructure and lipid content of the liver of the zebrafish, Brachydanio rerio, related to vitellogenin synthesis. Cell Tissue Res., 186: 297-308. 
SCHULZ, R., 1986, In vitro metabolism of steroid hormones in the liver and blood cells of male rainbow trout (Salmo gairdneri Richardson). Gen. Comp. Endocrinol., 64: 312-319.

SELMAN, K. \& WALLACE, R. A., 1989, Review cellular aspects of oocyte growth in teleosts. Zool. Sci., 6: 211-231.

SVEDÄNG, H. \& WICKSTRÖM, H., 1997, Low fat contents in female silver eels: indications of insufficient energetic stores for migration and gonadal development. J. Fish Biol., 50: 475-486.

TVERANGER, B., 1985, Variation in growth rate, liver weight and body composition at first sexual maturity in rainbow trout. Aquaculture, 49: 89-99.
VAN DE HURK, R. \& PEUTE, J., 1979, Cyclic changes in the ovary of the rainbow trout, Salmo gairdneri, with special references to sites of steredoigenesis. Cell Tissue Res., 199: 289-306.

VOGELBEIN, W. K., FOURNIE, J. W. \& OVERSTREET, R. M., 1987, Sequential development and morphology of experimentally induced hepatic melano-macrophage centres in Rivulus marmortatus. J. Fish Biol., 31: 145-153.

YONEDA, M., TOKIMURA, M., FUJITA, H., TAKESHITA, N., TAKESHITA, K., MATSUYAMA, S. \& MATSUURA, S., 1998, Reproductive cycle and sexual maturity of the anglerfish Lophiomus setigerus in the East China Sea with a note on specialized spermatogenesis. J. Fish Biol., 53: 164-178. 